\title{
Survey And Chemical Composition Of Plants Used As Herbal Remedies In Managing Poultry Animal Diseases In Ekiti-State, Nigeria.
}

\author{
M. K. Olanipekun (DR.) \\ Department Of Plant Science, Ekiti-State University, Ado-Ekiti, Nigeria
}

\begin{abstract}
Survey, Phytochemical, proximate and elemental analysis of plants used in treating poultry diseases were identified. A total of 27 plants belonging to 13 families were identified for treating various diseases of poultry ranging from common cold to diahorea, Coccidiosis, Newcastle diseases, Fowlpox etc. Argerantum conizoides, Helitricum indicum, Aframomum meleguata, Amaranthus spinosus, Azardiracta indica, Boervia diffusa, Bridelia ferruginea, Capsicum frutescens, Carica papaya, Chromolaena odorata, Cissampelos owariensis, Citrus aurantifolia, Datura stramonium and Elaeis guinensis among others were various plants identified. All the plants were found containing Alkaloid, tannins and saponins. However, Adansonia digitata, A. spinosus, A. indica, B.ferruginea, C. frutescence, C. papaya, T. vogeli and V. amygdalina contain Cardiac glycosides in addition to the Alkaloids, tannins and saponins. Proximate analysis revealed the presence of carbohydrates, protein, fat, ash and fibre in appreciable quantities. Capsicum annum has the highest fat content of $(71.16 \%)$ while Agerantum conizoides has the lowest of $3.72 \%$. Nicotiana tabacum has the highest Ash (30.59\%) while Morinda lucida has the least amount of (3.34\%) ash. Aloe vera has the highest percentage $(8.56 \%)$ of protein while Azardiractha indica has the lowest of $3.34 \%$ Ocimum gratisimum has the highest percentage of Fibre contents of $76.15 \%$ while Capscicum annum has the least of $8.61 \%$. Also, Potassium was found in higher quantity similarly to Iron, Zinc and Lead which were present at smaller and reasonable quantities.
\end{abstract}

Key words: Herbal, Poultry, Phytochemical, Proximate, Coccidiosis, Newcastle,

\section{Introduction}

The use of medicinal plants in the treatment of diseases have generated renewed interest in recent times, as herbal preparations are increasingly been used in health care system to treat various animal diseases especially poultry (Fajimi et al., 2004; Olanipekun et al; 2009). Poultry animals such as chickens, turkeys, ducks, geese etc are domestic animals that are commonly reared by the people of the rural areas at subsistence level because of various importance derived from it to alleviate poverty. The management is easier and the environmental factors are always conducive for their survival, thereby increasing their production. The products derived meet up with the peoples livelihoods both socially and educationally. The products generate income when it is sold, provide proteins in diet, thereby reducing and preventing the incidence of several diseases associated with the lack of protein such as worn-out tissues and weakness of the cells in the body.

Medicinal plants are of great importance to the health of individuals and their animals in a communities. Olanipekun and Tedela (2013) reported that well over $80 \%$ of rural people depend on the use and application of plants and plants extract in treating several ailments because of the natural components called bioactive ingredients that are exploited and isolated from plants, thus produced a definite physiological action on the body when used.

The use of plants for prophylactic and therapeutic purposes has long been recognized as one of the oldest forms of remedies used by humans especially the indigenous people. Medicinal plants aid in healing of several diseases in animals such as diarrhoea, mange, retained placenta, coccidiosis, Newcastle diseases, gastroenteritis, foot and mouth diseases, fowl pus among others because the values of plant lies in some chemical substances called bioactive molecules or ingredients from plants extract (Okwu,1999; 2001; Olanipekun 2011).

In our society today however, a large number of poultry animals are affected with different types of sicknesses and diseases which affect different parts and organs in their body. Orthodox medicine has done a lot in finding treatment and cure for different diseases by the means of using synthetic, orthodox and modern ways of treatment. However, drug resistance and occurrence of several fake and adulterated drugs in our society have brought the several users of the synthetic drug to the use of plants which have been found to be natural, having no side effects and cost effectives. A huge number of poultry animals are still saved by the use of herbs because their owners preferred the use of herbs to modern drugs probably because of cost, availability, proven efficacy 
and holistic nature of plants. In lieu of this, the study is to identify various medicinal plants used in treating poultry diseases with the aim of determining their chemical compositions thus complement with the synthetic.

\section{Materials and Methods}

The survey was carried out in five selected Local Government Areas (LGAs) of the Ekiti Central Senatorial District. The Local Governments area are Ado Local Government, Irepodun/Ifelodun Local Government Area, Ijero Local Government Area, Ekiti West Local Government Area and Efon-Alaaye Local Government Area, all in Ekiti-State. The survey spread across ten (10) local towns in the study areas

A well-structured, open-ended questionnaire and guided dialogue techniques were used to interview native livestock farmers and poultry keepers. The questionnaire was designed based on the needed information and interview was conducted in English language and in Ekiti dialect as situations demanded.

The respondents who chose to participate in the survey were asked to share their knowledge and experiences on the medicinal plants used in their communities to manage various types of poultry diseases combating poultry health in their locality. In each community, ten (10) individuals who had each maintained stable residence in the village for twenty (20) years or more were selected and interviewed. Information was received and documented.

Plants claimed to be beneficial in the treatment of various diseases were collected. Data obtained were collated and tabulated to give the botanical, family and local names of the various plant species. The voucher specimens were prepared and deposited at the herbarium of the Department of Plant Science, Ekiti State University, Ado-Ekiti. Also, Part of the identified samples were air-dried, ground and blended into powdered form to determine the phytochemical, Proximate and elemental composition so as to give a better and recordable understanding of their various chemical constituents which enables them to perform the noticeable preventive and healing functions

\subsection{Phytochemical Analysis of the identified Plants}

The qualitative analysis tests were carried out on the aqueous extract and on the powdered specimens using standard procedures as described by Adeleye et al; (1979) and Waterman (1993) to test for alkaloids and tannins and glycoside. Sofowora(1993), Trease and Evans (1989) and Harbone (1993) to determine the presence of saponins, in each of the identified species.

Test for Alkaloids (Adeleye et al; (1979) and Waterman (1993))

The qualitative analytical test for alkaloids in each of the plant sample was done according to Adeleye et al; (1979) and Waterman (1993) by stirring 0.5 gramme of dried and uniformly ground sample with $5 \mathrm{ml}$ of $1 \%$ (one percent) hydrogen chloride on a steam bath, after which $1 \mathrm{ml}$ of the solution was treated with "dragendorff's reagent; followed by observation for precipitate to confirm if alkaloid was present in the sample.

Test for Tannins: (Adeleye et al; 1979) and Waterman (1993). The qualitative analytical test for tannins in each sample was done by stirring 0.5 grammes of samples extract with $10(\mathrm{ml})$ of distilled water in a test-tube and later filtered. A few drops of $0.1 \%$ ferric-chloride was added, followed by observation for a brownish green or a blue-black coloration to confirm the presence of tannins in the samples .

Test for Glycosides : (Adeleye et al; (1979) and Waterman (1993)).

The qualitative analytical test for glycoside in each of the plant sample was done by dissolving little portion of the plant extract in pyridine followed by addition of few drops of $2 \%$ (two percent) sodium nitro-prusside and addition of few drops of $20 \%$ (twenty percent) sodium hydroxide. Observation for deep red coloration which fades to brownish yellow confirmed the presence of glycoside in the plant samples (Waterman, 1993).

Test for Saponins: Sofowora(1993); Trease and Evans (1989). The qualitative analytical test for saponins in the dried and uniformly ground samples was done by shaking 0.5 grammes of each sample with distilled water in a test-tube, followed by observation for persistent frothing on warming to confirm if saponins was present in the sample.

\subsection{Physiochemical analysis}

The mineral contents of Potassium, Iron, Zinc and Lead present in the plants were also determined by using dry ashing procedure as described by Association of Official Analytical Chemist (AOAC,1994). About 2 $\mathrm{g}$ of the sample was pre-ashed sample was then placed on a muffle and ashed at $500 \mathrm{oC}$ for about 3 hours or until the ash was white. After ashing, the sample was cooled and weighed. This was transferred into a $50 \mathrm{ml}$ volumetric flask by carefully washing the crucible with $5 \mathrm{ml}$ of $30 \% \mathrm{HCL}$. The solution was diluted to volume with iodized water. The solution was then used for individual mineral determination using spectrophotometer and flame photometer. 


\section{Results and Discussion}

A total number of 27 plants belonging to 15 families were identified in the study area. Leaves form the major part of the plants used (Table 1)

The study carried out on the plants samples revealed the indigenous knowledge and the potential of the plants used in treating various ailments ranging from tuberculosis, fever, diarrhoea, rheumatism, coccidiosis, cage fatigue, eggs malformation, chronic respiratory diseases, newcastle disease, fowlpox, etc (Table 2).

The different methods of preparation before application to ensure their effectiveness on diseases were identified and documented. The methods was found ranging from grinding of plant parts to powdered, preparation of extracts from the plant parts, cooking of some fruits and storing of some leaves in the poultry house against the outbreak of ectoparasites (Table 2).

The indigenous ways of describing disease symptoms were identified and compared with the scientific ways of identification and naming of various diseases to confirm their authentication (Table 3).

The plants were known to show medicinal activities as well as exhibiting physiological activity (Sofowora, 1993). Gill (1992) ascertained that Ocimum gratisimum leaves are useful in the treatment of catarrh, cough, and diarrhoea and chest pain. Similarly, Otoide and Kayode (2011), reported some of these plants, such as Chromolaena odorata, as been widely used in herbal medicine to treat different ailments.

Table 1: List of plants used in treating various diseases affecting poultry animals.

\begin{tabular}{|c|c|c|c|}
\hline Name of Plant & Family name & Local name & Part used \\
\hline $\begin{array}{l}\text { Aframomum melleguata } \mathrm{K} . \\
\text { Schum }\end{array}$ & Zingibiraceae & Alligator pepper & Seed \\
\hline Ageratum $\quad$ conizoides L & Compositae & Imi esu & Leaf \\
\hline Allium cepa & Liliaceae & Onion & Bulb \\
\hline Aloe vera L & Liliaceae & Aloe vera & Leaf \\
\hline Azadirachta Indica A. Juss & Meliaceae & Dongoyaro & Leaf \\
\hline Black oil & Arecaceae & Adin & Extract \\
\hline $\begin{array}{ll}\text { Capsicum annum L } \\
\end{array}$ & Rutaceae & Pepper & Fruit \\
\hline Citrus aurantifoliaL & Rutaceae & Orange & Fruit \\
\hline Citrus sinensis L & Rutaceae & Lime & Fruit \\
\hline Coccinea $\quad$ barteri Hook & Cucurbitaceae & Ikirikiri & Fruit \\
\hline Ficus exasperate Vahl & Moraceae & Epinpin & Leaf \\
\hline Gossypium spp & Malvaceae & Cotton plant & Leaf \\
\hline Kalanchoe crenata & Crassulaceae & Urere & Leaf \\
\hline Khaya Senegalensis A.Juss & Meliaceae & Oganwo & Leaf/Back \\
\hline Mormodica charantiaL & Cucurbitaceae & Ejirin & Leaf \\
\hline Musa paradisiacaL & Musaceae & Ogede & Fruit \\
\hline Nicotiana tabaccumL & Solanaceae & Tobacco & Leaf \\
\hline Ocimum gratissimumL & Leguminoseae & Scent leaf & Leaf \\
\hline Pakia biglobosa Jacq & Leguminoseae & Locust beans & Fruit \\
\hline Phaseolus lunatus L & Leguminoseae & Beans & Seed \\
\hline Sorghum bicolor L & Poaceae & Sorghum plant & Leaf \\
\hline Spondia mombin L & Anarcadiacaea & Ewe iyeye & Leaf \\
\hline Telfaria Occidentalis Hook. & Cucurbitaceae & Pumpkin plant & Leaf \\
\hline Vernonia Amygdalina Del & Compositae & Bitter leaf & Leaf \\
\hline Zea mays $\mathrm{L}$ & Poaceae & Maize plant & Grain \\
\hline
\end{tabular}

Table 2: Methods of Preparation and Mode of Application of the Identified Plants in the Study Area.

\begin{tabular}{|c|c|c|c|}
\hline BOTANICAL NAME & LOCAL NAME & DISEASED TREATED & $\begin{array}{l}\text { METHOD } \\
\text { PREPARATION/APPLICATIO } \\
\mathrm{N}\end{array}$ \\
\hline Aframomum & Ata-ire & Chicken pox & $\begin{array}{l}\text { Grinding and Sprinkling on } \\
\text { surface }\end{array}$ \\
\hline Conizoides & Imiesu & $\begin{array}{l}\text { Tuberculosis/ Wound } \\
\text { healing }\end{array}$ & $\begin{array}{l}\text { Extract }+ \text { pepper/applied on the } \\
\text { surface }\end{array}$ \\
\hline Allium cepa & Onion & Lice/Tick & Extract/ Rubbing on surface \\
\hline Aloe vera & Aloe vera & Newcastle/ Chickenpox & $\begin{array}{l}\text { Slice in water/ Through the } \\
\text { mouth }\end{array}$ \\
\hline Azadirachta & Dongoyaro & Fever, Diarrhea & Extract/Through the mouth \\
\hline $\begin{array}{l}\text { Capsicum } \\
\text { /Through the mouth } \\
\text { annum } \\
\text { Tubercculosis } \\
\text { /Through the mouth } \\
\text { annum } \\
\text { Tubercculosis }\end{array}$ & Pepper & Newcastle/ Tuberculosis & $\begin{array}{l}\text { Powdered grain/mixed with } \\
\text { food }\end{array}$ \\
\hline
\end{tabular}


Survey And Chemical Composition Of Plants Used As Herbal Remedies In Managing Poultry....

\begin{tabular}{|c|c|c|c|}
\hline arantifolia & Lime & $\begin{array}{l}\text { Lice/Leg weakening/ } \\
\text { Rheumatism }\end{array}$ & $\begin{array}{l}\text { Whole fruits is put in the animal } \\
\text { house; Apply extracts on the } \\
\text { leg. }\end{array}$ \\
\hline Citrus sinensis & Orange & $\begin{array}{l}\text { Leg weakening wound } \\
\text { healing Rheumatism }\end{array}$ & $\begin{array}{l}\text { Applying extracts } / \text { Through } \\
\text { the mouth }\end{array}$ \\
\hline Coccinea barteri & Ikirikiri & $\begin{array}{l}\text { Newcastle }, \quad \text { Diarrhea, } \\
\text { Chickenpox, Coccidiosis }\end{array}$ & $\begin{array}{l}\text { Slicing in water/ Through the } \\
\text { mouth }\end{array}$ \\
\hline Ficus exasperata & Erepin/ Epinpin & Ectoparasites & Storing in animal house \\
\hline Gossypium spp & Owu & $\begin{array}{l}\text { Blood shortage, Blood } \\
\text { purifier }\end{array}$ & $\begin{array}{l}\text { Collecting seed extracts } \\
\text { /Through the mouth }\end{array}$ \\
\hline Kalanchoe crenata & Urere & Newcastle, Squeezing & $\begin{array}{l}\text { extract /Through } \\
\text { the mouth }\end{array}$ \\
\hline senegalensis & Oganwo & $\begin{array}{l}\text { Newcastle, Diarrhea, } \\
\text { Coccidiosis, Dysentery }\end{array}$ & $\begin{array}{l}\text { Grinding to powder }+ \text { potash } \\
\text { /Through the mouth }\end{array}$ \\
\hline Morinda lucida & Oruwo & $\begin{array}{l}\text { Diarrhea, Dysentery and } \\
\text { Fever }\end{array}$ & $\begin{array}{l}\text { Boiling in water/Through } \\
\text { the mouth }\end{array}$ \\
\hline Mormodica & Ejirin & Diarrhea and Dysentery & $\begin{array}{l}\text { Leaf } \\
\text { extract/Through the mouth }\end{array}$ \\
\hline Paradisiaca & Plantain & $\begin{array}{l}\text { Leg weakening, } \\
\text { rheumatism, Egg and Bone } \\
\text { malformation }\end{array}$ & $\begin{array}{l}\text { Eaten cooked fruit/Through the } \\
\text { mouth }\end{array}$ \\
\hline Nicotiana & Tobacco & Ectoparasites and worm. & $\begin{array}{l}\text { Extract }+ \text { salt /Through } \\
\text { the mouth, Rubbing on body }\end{array}$ \\
\hline $\begin{array}{l}\text { Ocimum } \\
\text { grattissimum }\end{array}$ & Scent leaf & $\begin{array}{l}\text { Diarrhrea, } \\
\text { Squeezing, Cholera and } \\
\text { Chicken pox }\end{array}$ & $\begin{array}{l}\text { extract / Through the } \\
\text { mouth }\end{array}$ \\
\hline $\begin{array}{l}\text { Parkia } \\
\text { biglobosa }\end{array}$ & Locust beans & $\begin{array}{l}\text { Chicken pox, and } \\
\text { Coccidiosis }\end{array}$ & $\begin{array}{l}\text { Grinding fruit, Sprinkling on } \\
\text { affected parts }\end{array}$ \\
\hline $\begin{array}{r}\text { Phaseolus } \\
\text { Lunatus }\end{array}$ & Beans & $\begin{array}{l}\text { Chicken pox and } \\
\text { Coccidiosis }\end{array}$ & $\begin{array}{l}\text { Grinding to powder; } \\
\text { Sprinkling on the affected parts }\end{array}$ \\
\hline $\begin{array}{l}\text { Sorghum } \\
\text { bicolor }\end{array}$ & Sorghum & Blood shortage & $\begin{array}{l}\text { Boiling } \\
\text { in }\end{array}$ \\
\hline Mombin & Iyeye & Shelless eggs & $\begin{array}{ll}\text { grinding to } & \text { powder / } \\
\text { Through } & \text { the mouth } \\
\end{array}$ \\
\hline occidentalis & Pumpkin & Blood shortage & $\begin{array}{l}\text { Squeezing plant } \\
\text { extract/ } \\
\text { Through the mouth }\end{array}$ \\
\hline $\begin{array}{l}\text { Vernonia } \\
\text { amygdalina }\end{array}$ & Bitter leaf & $\begin{array}{l}\text { Newcastle, Diarrhea, } \\
\text { Blood, Constipation And } \\
\text { worm. }\end{array}$ & $\begin{array}{l}\text { Leaf extract/ Through the } \\
\text { mouth }\end{array}$ \\
\hline Zea mays & Maize plant & Newcastle & $\begin{array}{l}\text { Heating dry grain on coal / } \\
\text { Through the mouth }\end{array}$ \\
\hline
\end{tabular}

Table 3 shows that Plants were found to contain secondary metabolites such as alkaloids, tannins, Glycosides and saponins. All the tested botanicals were found to contain alkaloids, tannins and saponins expect Jatropha gosypifiola that does not contain alkaloids. Saponins were present in fifteen botanicals and these are; Acacia arabica, Amaranthus spinosus, Azardiracta indica, Bridelia feruginea, Capsicum frutescence, Carica papaya, Chromolaena odorata, Cisampelous owariensis, Jatropha gossypifolia, Lagenaria siceraria, Momodica charantia, Musa parasidiaca,Nicotiana tabacum, Ocimum basilicum Solanum nodiflora Talinum triangulare and Zea mays. Similarly, Adansonia digitata, Amaranthus spinosus, Azardiracter indica, Bridelia ferruginea, Capsicum frutescense, Carica papaya, Tephrosia vogeli and Venona amygdalina were found containing Cardiac Glycosides. The presence of alkaloids and tannins on the seeds of Aframomum meleguata, rhizomes of Zingiber officinale and the leaves of the remaining plant species agreed with the findings of Sofowora (1993), Trease and Evans (1989), Edeoga et al; (2006), Otoide and Kayode (2011) who had earlier reported that Ocimum bascilicum extracts possessed antimicrobial activities which can be used to treat several bacterial infections. Similarly, the presence of tannins confirms the astringent properties and flavour found in tea, this makes the plants useful in the treatment of inflammatory skin eruption, wound healing and bowel condition. Saponins aids in wound healing and bleeding treatments, they are produced by plants as defence mechanism to stop attack by foreign pathogen and show tumour inhibiting activities on animals, thus make them to be natural antibiotics. Iniaghe et al 2009; Akindahunsi and Salawu 2005. Therefore, the plants have the potential when used.

The results of the proximate analysis revealed the various quantity of bioactive ingredients presents which ranges from crude proteins to carbohydrates, fats, fibre, ash and moisture contents. A. vera has the highest percentage $(6.53 \%)$ of carbohydrate while Aframomum melegueta, Capsicum annum and Coccinia barteri have the least $(0.38 \%)$ of carbohydrates. The plants appeared not to be a good source of carbohydrate. Carbohydrate provides energy that are needed in the diet to ensure efficient oxidation of fat. A. meleguata was 
found to have the highest crude fibre content of $51.38 \%$ while A. conizoides has the least percentage $3.72 \%$. Crude fibre serves as roughages in the diet to reduce the starch intake, holding the entire nutrient and every other components of the botanicals and food nutrients. It enhances gastrointestinal functions and also prevent constipation. Hence, there is reduction in the risk of coronary heart diseases, hypertension, diabetes and breast cancer(Ishida et al; 2000). N. tobaccum has the highest percentage $(30.59 \%)$ of fat content while M.lucida has the least percentage $(3.34 \%$ ) of fat content. The low content of fat will help and be useful for the poultry birds as weight reducing diet.( Emebu and Ayinka, 2011). A. vera was found to have the highest crude protein content of $15 \%$ while $\mathrm{C}$. annum has the least percentage of $3.50 \%$. The available protein content were relatively lower than what was reported by Nkafamiya et al; 2010 who reported $20.27 \%$ and $17.24 \%$ for F. asperifolia and F. sycamorus respectively, however they can still be ranked as a potential source of protein that could be used for the building-up materials for body structures, regulation and control of body processes in poultry. Therefore they can be used as a protein supplement in poultry animal diet and medicines. A. vera has the highest percentage of moisture content of $6.53 \%$ while A. meleguata, C. annum and C. barteri has the least percentage of $0.38 \%$. The moisture contents of the botanicals were low, thus, prevents microbial growth during storage and increase the shelf-life however, moistening the body cells of the animals, thereby preventing the incidence and occurrence of dryness.

Table 3: Phytochemical analysis of the identified plants in the study area

\begin{tabular}{|c|c|c|c|c|}
\hline Name of the plants & Alkaloids & Tannins & Saponins & Cardiac glycosides \\
\hline Aframomum meleguata & + & + & - & - \\
\hline Ageratum Imiesu & + & + & + & - \\
\hline Allium cepa & + & + & + & + \\
\hline $\begin{array}{l}\text { Azadirachta } \\
\text { Indica }\end{array}$ & + & + & + & + \\
\hline Capsicum $\quad$ annum & + & + & + & + \\
\hline Citrus aurantifolia & + & + & + & - \\
\hline Citrus sinensis & + & + & + & - \\
\hline \multicolumn{5}{|l|}{$\begin{array}{l}\text { Coccinea } \\
\text { barteri }\end{array}$} \\
\hline Elaeis guinensis & + & + & - & - \\
\hline Ficus exasperata & + & + & - & - \\
\hline Gossypium spp & + & + & + & + \\
\hline $\begin{array}{l}\text { Khaya } \\
\text { Senegalensis }\end{array}$ & + & + & + & + \\
\hline Mormodica charantia & + & + & + & - \\
\hline Musa paradisiaca & + & + & + & - \\
\hline Nicotiana tabaccum & + & + & + & - \\
\hline Ocimum gratissimum & + & + & + & + \\
\hline Pakia biglobosa & + & + & - & - \\
\hline Spondias mombin & + & + & + & - \\
\hline \multicolumn{5}{|l|}{$\begin{array}{l}\text { Telfaria } \\
\text { Occidentalis }\end{array}$} \\
\hline $\begin{array}{l}\text { Vernonia } \\
\text { amygdalina }\end{array}$ & + & + & - & + \\
\hline Zea mays & + & + & + & - \\
\hline
\end{tabular}

Table 3: Results of the Proximate analysis of the identified botanicals in the study area.

\begin{tabular}{llccccc}
\hline Plants & Fat & Ash & Protein & Moisture & $\begin{array}{r}\text { Carbohy } \\
\text { drate }\end{array}$ & Fibre \\
& $\%$ & $\%$ & $\%$ & $\%$ & $\%$ & $\%$ \\
\hline
\end{tabular}




\begin{tabular}{lcccccc}
\hline $\begin{array}{c}\text { Aframomum } \\
\text { melegueta }\end{array}$ & 51.38 & 12.54 & 2.58 & 4.00 & 0.38 & 29.12 \\
$\begin{array}{c}\text { Ageratum } \\
\text { conizoides }\end{array}$ & 3.72 & 15.60 & 1.91 & 15.00 & 0.58 & 63.19 \\
$\begin{array}{c}\text { Aloe vera } \\
\text { Azadirachta }\end{array}$ & 13.07 & 7.00 & 8.56 & 1.39 & 6.53 & 63.45 \\
indica & 10.44 & 20.92 & 0.69 & 15.00 & 0.47 & 52.08 \\
$\begin{array}{l}\text { Capsicum } \\
\text { annum }\end{array}$ & 71.16 & 14.71 & 1.64 & 3.50 & 0.38 & 8.61 \\
$\begin{array}{c}\text { Coccinia } \\
\text { barteri }\end{array}$ & 56.01 & 11.72 & 1.90 & 5.00 & 0.38 & 24.99 \\
$\begin{array}{l}\text { Morinda } \\
\text { lucida }\end{array}$ & 20.09 & 3.34 & 2.02 & 5.00 & 0.45 & 69.10 \\
$\begin{array}{l}\text { Mormodica } \\
\text { charantia }\end{array}$ & 24.08 & 16.53 & 1.69 & 10.00 & 1.10 & 46.60 \\
$\begin{array}{l}\text { Nicotiana } \\
\text { tobaccum }\end{array}$ & 21.48 & 30.59 & 1.62 & 10.00 & 1.16 & 35.15 \\
$\begin{array}{l}\text { Occimum } \\
\text { gratissimum }\end{array}$ & 12.35 & 5.00 & 1.87 & 4.00 & 0.63 & 76.15 \\
$\begin{array}{c}\text { Spondias } \\
\text { mombins }\end{array}$ & 22.32 & 14.27 & 2.06 & 12.50 & 0.91 & 41.94 \\
$\begin{array}{l}\text { Telfaria } \\
\text { occidentalis }\end{array}$ & 17.01 & 8.15 & 3.44 & 11.50 & 1.07 & 58.83 \\
$\begin{array}{l}\text { Venona } \\
\text { amygdalina }\end{array}$ & 18.83 & 13.42 & 1.75 & 1.50 & 0.55 & 64.45 \\
\hline & & & & & & \\
\hline
\end{tabular}

The results gotten from the minerals analysis of the botanicals indicated the relevance of this minerals in the identified plant. The potassium $(\mathrm{K})$ content values recorded in this study were in line with the $1.33 \%$ recorded in the leaves of H. ulmoides ( Andzouana and Mombouli, 2011), Maize (Kouakou et al; 2008) and V. ferruginea leaves. Potassium builds proteins, breakdown and use carbohydrates, builds muscles and maintain normal body growth.

Iron $(\mathrm{Fe})$ is a minor or micronutrient which is a component of Feredoxin which plays an important role in Nitrogen fixation, Iron is essential for the synthesis of protein. Iron builds muscles and it helps regulates the growth of the cells. The report of Iron contents confirms the assertions of Andzouana and Mombouli, 2011 that the iron content of rice, millet grains and maize respectively ranges from $0.05 \%$ and $0.04 \%$ respectively.

Lead $(\mathrm{Pb})$ is present in all the botanicals in trace quantity of below 1.00. It acts as catalyst to trigger many biochemical reactions in the body cells. High concentration of lead causes lead poisoning which causes mass death by poisoning of the body cell organelles ( i.e it is lethal to the body cells). Zinc ( $\mathrm{Zn}$ ) is also a micronutrient and it functions as activators of some enzymes like carbonic anhydrase and alcohol dehydrate (Table 4)

Table 4: Elemental Composition of the Identified Botanicals

\begin{tabular}{lcccc}
\hline $\begin{array}{c}\text { S/n Plants } \\
\text { name }\end{array}$ & $\begin{array}{c}\text { potassium }(\mathrm{k}) \\
(\mathrm{ppm})\end{array}$ & $\begin{array}{c}\text { iron (fe) } \\
(\mathrm{ppm})\end{array}$ & $\begin{array}{c}\text { zinc }(\mathrm{zn}) \\
(\mathrm{ppm})\end{array}$ & $\begin{array}{c}\text { lead }(\mathrm{pb}) \\
(\mathrm{ppm})\end{array}$ \\
\hline $\begin{array}{l}\text { Aframomum } \\
\text { melleguata }\end{array}$ & 120 & 3.10 & 0.71 & 0.10 \\
$\begin{array}{l}\text { Ageratum } \\
\text { conizoides }\end{array}$ & 139 & 4.87 & 0.93 & 0.10 \\
$\begin{array}{l}\text { Aloe vera } \\
\text { Azadirachta } \\
\text { indica }\end{array}$ & 125 & 2.00 & 0.44 & 0.10 \\
& 146 & 2.17 & 0.55 & 0.20 \\
\hline
\end{tabular}




\begin{tabular}{lcccc}
\hline $\begin{array}{c}\text { Capsicum } \\
\text { annum }\end{array}$ & 148 & 0.96 & 0.29 & 0.10 \\
$\begin{array}{c}\text { Coccinia } \\
\text { barteri }\end{array}$ & 135 & 4.01 & 0.97 & 0.10 \\
$\begin{array}{c}\text { Morinda } \\
\text { lucida }\end{array}$ & 130 & 2.01 & 0.50 & 0.09 \\
$\begin{array}{l}\text { Mormodica } \\
\text { charantia }\end{array}$ & 93.1 & 2.41 & 0.66 & 0.11 \\
$\begin{array}{l}\text { Nicotiana } \\
\text { tobaccum }\end{array}$ & 120 & 4.01 & 0.47 & 0.14 \\
$\begin{array}{l}\text { Occimum } \\
\text { gratissimum }\end{array}$ & 132 & 4.27 & 0.80 & 0.30 \\
$\begin{array}{c}\text { Spondia } \\
\text { mombin }\end{array}$ & 131 & 2.92 & 0.56 & 0.10 \\
$\begin{array}{l}\text { Telfaria } \\
\text { occidentalis }\end{array}$ & 141 & 3.39 & 0.40 & 0.12 \\
$\begin{array}{l}\text { Vernonia } \\
\text { amygdalina }\end{array}$ & 78.1 & 3.31 & 0.71 & 0.10 \\
\hline
\end{tabular}

KEY: parts per million (ppm)

\section{Conclusion}

The result obtained revealed that the plants contained various properties which were found useful as remedies against different poultry diseases in the study area. The appreciable amounts of proteins, carbohydrates, fats, moisture content, fibres, Phosphorus, Potassium, Iron and Lead indicated that the botanicals were prophylactic and nutritionally important. Therefore, the botanicals could be recommended as a basis for the development of synthetic drugs for the treatment of various animal diseases.

However, further research should be done on the plants for their specific purposes, effectiveness and their bioactive potential to ascertain their authentication.

\section{References}

[1]. Akindahunsi AA and Salawu SO, 2005. Phytochemical screening, nutrient and anti-nutrient compositions of selected tropical green leafy veghetables. A.Journal of Biochemistry 4: 97-105.

[2]. Andzouana and Mombouli 2011, Chemical composition and phytochemical screening of the leaves of Hymenocardia ulmoides and Vitex ferruginea. Parkistinal journal of Nutrition 10:1183-1189

[3]. Edeoga, HO; Okwu DE and Mbaebie BO. 2006, Chemical composition of Hyptis suqveolens and Ocimum gratisimum hybrids from Nigeria. African Journal of Biotechnology vol. 5 (10) PP.892-895

[4]. Fajimi and Taiwo 2004, Herbal remedies in animal parasitic diseases in Nigeria, African Journal of Biotechnology vol. 4 (4) pp. 303-30

[5]. Gbile, ZO. 1986, Ethnobotany, Taxonomy and conversion of medicinal plants. In. Sofowora, A(ed). The state of medicinal plants research. The University of Ife press, Nigeria 404pp

[6]. Gbile, ZO. 1991 Identification and pharmaceutical importance of medicinal plants. Ibadan: Forestry Research Institutes of Nigeria, Unpublished paper.

[7]. Gill, LS. 1992 Ethnomedicinal uses of plants in Nigeria, University of Benin Press, Nigeria. P.296.

[8]. Iniaghe OM, Maloma SO, Adebayo JO, (2009). Proximate composition and phytochemical constituents of leaves of some Acalypha species. Parkistan Journal of Nutrition 8(3) : 256-258.

[9]. Okwu, DE. 1999, Flavouring properties of spices on cassava Fulu. Afr. J. Root Tuber Crops 3(2): 19-21.

[10]. Okwu DE. 2001, Evaluation of the chemical composition of indigenous spices flavouring agents. Global J. Pure and Appl. Sci. 7(3). $455-459$.

[11]. Olanipekun, MK. 2011, Studies on Ethnoveterinary botanicals and some aspect of conservation in Ekiti-State. Unpublished Ph. D. Thesis, EKSU, Ado-Ekiti.

[12]. Olanipekun, MK and Tedela, PO. 2013 Etno-medicinal importance of some selected plants used for the treatments of Ruminants Animal Diseases in Ekiti-State, Nigeria. J. of Agric. and veterinary science (IOSR-JAVS). Pp. 16-22

[13]. Otoide and Kayode 2011, Phytochemical study of some plants commonly used as herbal remedies in Southern Nigeria. J. of Bulletin of Pure and Applied Sciences, V30b, Pp. 33-40

[14]. Pandey, BP.1980, Economic botany for degree honours and Postgraduate Students. S. Chand and company Limited Ltd. Ram. Vagar.

[15]. Sofowora, A.1993, Medicinal plants and Traditional Medicine in Africa, 2nd Edition spectrum book Ltd. Ibadan

[16]. Trease GE. and Evans. WC.1989, Pharmacognosy. 11th edition Braillar Tridel Can. Macmillian publishers.

[17]. Waterman, PG.1993, Methods in Plants Biochemistry Vol. 8 Academic press, Cambridge. 